\title{
Drugi vatikanski koncil i poslijekoncilska obnova na stranicama Glasa Koncila od 1963. do 1972.
}

\author{
Anto Mikić*
}

\begin{abstract}
Sažetak
Autor rada, na temelju vlastite analize sadržaja Glasa Koncila u prvih 10 godina postojanja toga lista (1963.-1972.), arhivske građe i relevantne literature, istražuje na koji je način taj katolički (dvo)tjednik pratio održavanje Drugog vatikanskog koncila (1962.-1965.) i provedbu (poslije)koncilske obnove u Crkvi $u$ hrvatskom narodu, ali $i$ napetosti $i$ polemike između „progresista“ $i$, konzervativaca" koje su obilježile taj proces. U radu se analiziraju i načini na koje je Glas Koncila tu (poslije)koncilsku obnovu promicao te joj i sam nastojao dati svoj doprinos. Na taj se način u radu propituje teza koju su već ranije postavili neki drugi autori, prema kojoj je Glas Koncila odigrao važnu ulogu u recepciji/ prihvaćanju Drugog vatikanskog koncila u Crkvi u Hrvatskoj.

Ključne riječi: Glas Koncila, Drugi vatikanski koncil, Poslijekoncilska obnova, progresisti, tradicionalisti, Tomislav Šagi-Bunić, Živko Kustić
\end{abstract}

\section{Uvod}

Održavanje Drugog vatikanskog koncila (1962.-1965.) bio je neposredan povod, a upoznavanje hrvatske vjerničke javnosti s njime i njegovim odlukama glavni razlog osnivanja i biltena Glas s Koncila - koji je u 11 brojeva, umnažan ciklostilom, izlazio tjedno od 4. listopada do 19. prosinca 1962., u vrijeme prve sjednice Koncila (Duda, 1972) — kao i novina Glas Koncila, ${ }^{1}$ koje su pokrenute

* Dr. sc. Anto Mikić, poslijedoktorand, Hrvatsko katoličko sveučilište, Odjel za komunikologiju. Adresa: Ilica 242, 10000 Zagreb, Hrvatska. E-pošta: anto.mikic@unicath.hr

1 Čini se da je njegov utemeljitelj nadbiskup Franjo Šeper u početku očekivao da će i Glas Koncila biti privremeno glasilo koje će »izlaziti za vrijeme trajanja II. Vatikanskog koncila« (NAZ, 1963), jer je upravo takva formulacija upotrijebljena u dekretu od 10. rujna 1963. kojim je nadbiskupskog kancelara Dragutina Hrena imenovao urednikom. A kad je postalo jasno da su Glas Koncila postale novine koje su „nadrasle“ samo praćenje odvijanja Koncila, a tematskom usmjerenošću proširile krug svojeg interesa, u službenoj odluci o njegovu ustanovljenju s kraja 1963. godine nadbiskup Šeper nalaže kako taj vjerski list, među ostalim, ima služiti »izvještavanju o događajima u katoličkom svijetu i na području vjerskog života uopće, a napose u vezi s II. Vatikanskim koncilom« (Arhiv Glasa Koncila, 1963). 
kao dvotjednik krajem rujna 1963. godine, uoči nastavka koncilskih zasjedanja (Mikić, 2016, 32-39).

Ne čudi stoga činjenica kako je, s jedne strane, taj vjerojatno i najvažniji crkveni događaj 20. stoljeća na više načina obilježio sadržaj Glasa Koncila, a s druge strane te novine odigrale su važnu ulogu u prihvatu (recepciji) Drugog vatikanskog koncila u Crkvi u hrvatskom narodu, što je dijelom i prepoznato u našoj domaćoj stručnoj teološkoj javnosti (Duda, 1996; Baloban, 2000; Zovkić, 2005; Mataušić, 2005). No, sve donedavno, te teze nisu bile potkrijepljene sustavnijom analizom sadržaja toga lista. Tek se o 50. obljetnici Glasa Koncila 2013. godine taj „nedostatak“ počeo „ispravljati“ pa je organiziran međunarodni znanstveni skup na tu temu, no radovi s toga skupa u trenutku predaje ovoga rada nisu objavljeni, pa ni njegovi zaključci još uvijek nisu dostupni stručnoj i zainteresiranoj javnosti, stoga ih ne koristim ni u ovom radu. Istim povodom i sadašnji glavni urednik lista Ivan Miklenić objavio je prigodnu knjigu (Miklenić, 2013) koja je koristan prilog i ovoj temi no ona, kako to i autor u samom uvodu napominje, nije imala znanstvenih pretenzija, te se zadržala uglavnom na publicističkoj razini prikaza tog lista. Ovaj će se rad, stoga, temeljiti prije svega na vlastitom istraživanju, provedenom za potrebe izrade doktorske disertacije (Mikić, 2016).

\section{Drugi vatikanski koncil — izvješća o zasjedanjima i koncilskim dokumentima}

U skladu s uređivačkom politikom prema kojoj Glas Koncila trebaju biti novine, odnosno list u kojem najvažniju ulogu imaju vijesti i druge novinarske forme, i Drugi vatikanski koncil u njima je praćen prije svega na novinarski način. Stoga je list prenosio ne samo sadržaj dokumenata izglasanih na Koncilu, nego i sam njegov tijek i sadržaj rasprava, dakako u mjeri u kojoj su mu to uvjeti u kojima je djelovao i ograničeni izvori informacija koje je imao dopuštali. S tim je ciljem, u vrijeme koncilskih zasjedanja, već od br. 2, 20. listopada 1963., uveo i posebnu rubriku Dnevnik Koncila, u kojoj je donosio vijesti povezane sa zasjedanjima. No, i izvan te rubrike, pa i izvan vremena zasjedanja, list je prenosio novosti vezane uz koncilske rasprave. Također, u svojim izvješćima, prikazima i intervjuima nije bježao ni od „kontroverznih“ tema u vezi sa samim održavanjem Koncila. Primjerice, kad su neke svjetovne novine u svijetu, pa i kod nas, u listopadu 1964. prenijele vijesti kako je Koncil zapao u svojevrsnu krizu, te kako je skupina koncilskih otaca zatražila i posredovanje samog pape Pavla VI., u Glasu Koncila je o tome otvoreno izvještavano, uz tvrdnju kako tu »nema senzacije « te se »tako duboka pitanja i tako različiti stavovi vrlo brzo is mnogo dobronamjernosti svode u normalan i konstruktivan tok « (Anon., 1964d). Nisu prešućivane ni vijesti o iznenadnim obratima do kojih je dolazilo tijekom koncilskih sjednica. Tako se, primjerice, otvoreno javlja kako je došlo do velikih promjena u pripremi „Trinaeste sheme“, koja je kasnije prerasla u Pastoralnu konstituciju o Crkvi u suvremenom svijetu Gaudium et spes (Anon., 1965b). 
Dakako, sami koncilski dokumenti - konstitucije, dekreti i deklaracije bili su u središtu pozornosti lista u vrijeme trajanja Koncila, osobito oni njihovi elementi koji su predstavljali svojevrsnu novost u odnosu na raniju praksu Crkve. Kako zbog opsega ovoga rada nije moguće navesti izvješća o svim koncilskim dokumentima koja je list objavio, zadržat ću se samo na onima kojima je na njegovim stranicama dana veća pozornost.

Primjerice, Dogmatska konstitucija o Crkvi, osim što je predstavljena (Anon., 1964o), kasnije biva obrađena i u intervjuu s koncilskim teologom Tomislavom Šagi-Bunićem (Anon., 1964h), a potom je objavljen i cijeli niz članaka u kojima se iz pera istog teologa ta konstitucija tumačila, po nekim njezinim bitnim temama (Šagi-Bunić, 1965a-g; 1966a). Velika je pozornost posvećena i Deklaraciji o vjerskoj slobodi. Najprije je najavljena (Anon., 1965e), a kasnije je njezin širi prikaz i aktualizaciju donio Šagi-Bunić (1968a) te je u drugom dijelu prikaza od države zatražio da osigura stvarnu jednakopravnost vjernika i onih koji ne vjeruju da slobodno žive svoje uvjerenje, i to ne samo u privatnoj, nego i u društvenoj sferi (Šagi-Bunić, 1968b).

No, najveća pozornost posvećena je tzv. Shemi o prisutnosti Crkve u suvremenom svijetu, odnosno (budućoj) Pastoralnoj konstituciji o Crkvi u suvremenom svijetu Gaudium et spes. »Tek ova shema pokazat će koliko je Crkva sposobna izaći iz svojih unutrašnjih problema da se posveti općeljudskim interesima« (Anon., 1964a), konstatira tako komentator Glasa Koncila u listopadu 1964., a u istom se broju, u prikazu nacrta te sheme i komentarima svjetskog tiska o njoj, ona već u naslovu članka ocjenjuje kao »najzanimljivija« (Anon., 1964e, 3). Kasnije list prenosi i istupe (nad)biskupa Frane Franića, Franje Kuharića i Franje Šepera u raspravi o tom dokumentu (Anon., 1964g), a potom i ponovno nadbiskupa Šepera u okviru rasprave o toj Konstituciji, u kojoj je on progovorio o temi odnosa prema ateizmu (Anon., 1965c). Kad je u pitanju taj dio Konstitucije, koji govori o ateistima, list donosi čak i njegov cjeloviti prijevod (Anon., 1966d).

Naposljetku, nakon završetka Koncila, Pastoralna konstitucija Gaudium et spes još je jedanput prikazana iz pera Mije Škvorca (1966), a pojedinim se temama sadržanima u tom dokumentu u više navrata bavio i Tomislav Šagi-Bunić (1966b-d).

Važnost svih tih izvješća, prikaza, tumačenja i aktualizacije pojedinih dokumenata Drugog vatikanskog koncila tim je veća što se domaća crkvena javnost s odlukama Drugog vatikanskog koncila, osobito za vrijeme samog zasjedanja, mogla informirati gotovo isključivo sa stranica Glasa Koncila, jer sve do 1970. godine na hrvatskom jezičnom prostoru nisu bili dostupni ni prijevodi svih koncilskih dokumenata.

\section{Drugi vatikanski koncil — provedba i crkvena obnova}

Osim što je izvještavao o događajima i raspravama na Drugom vatikanskom koncilu, te prenosio i tumačio dokumente koji su na njemu usvajani, list je za vrijeme Koncila i nakon njega zauzeto promicao i provedbu njegovih zaključaka u domaćoj Crkvi. 
Već od prvog broja Glas Koncila budio je velika očekivanja od Koncila, u smislu obnove Katoličke crkve, te je od samog početka poticao i „podgrijavao“ reformske procese u vezi s unutarcrkvenim promjenama: »Mnogi misle, da sada možemo zbaciti historijske maske i obzire, kojima je povijest hladnokrvno ubijala duh, ideje i zanos. Kad se jednom dotuče konstantinovsko shvaćanje sekulariziranoga kršćanstva; kad se ukloni svaka želja za cezaropapizmom; kad se izvučemo iz feudalnih prekoncepcija, radi kojih je nezdrava klasna podjela razjedinila prvobitno bratsko kršćanstvo; kad se oslobodimo takozvane crkvene malograđanštine i formalizma - doći ćemo na čistinu, gdje se jasnije vidi i svjesnije hoće. [...] Trebalo bi nadalje dokinuti sve teretno, prepuno historijskog nepotrebnog balasta i izanđalo. Što ce nam toliki gotovo nedolični običaji u paraliturgiji i obzirom na relikvije, u odijevanju i naslovima, u nezdravim i malne sujevjernim pobožnostima (Presmiono? Ne plašimo se - misli su iz srca i ustiju onih na vrhu; jedan je postao papa...)«(Anon., 1963, 7).

\subsection{Glas Koncila u službi promicanja crkvene obnove u duhu Drugog vatikanskog koncila}

Kako je „najvidljivija“, vanjska promjena proizišla iz Koncila bila ona na području liturgije - uvođenje narodnog jezika, „okretanje“ oltara, uvođenje koncelebracije i dr. - ne čudi da je upravo tom segmentu i u Glasu Koncila posvećivana osobita pozornost (Mikić, 2016, 79-87).

Već i prije uvođenja konkretnih promjena u liturgijska slavlja u domaćoj $\mathrm{Cr}$ kvi, list je te promjene najavljivao, primjerice predstavljajući Instrukciju o primjeni Konstitucije o svetoj liturgiji (Anon., 1964n). Osim toga, list je domaću javnost pripremao i javljajući o uvođenju promjena u izgled liturgijskog slavlja u svijetu. Tako, primjerice, i prije završetka Koncila, u lipnju 1964., javlja o prvoj koncelebriranoj misi latinskog obreda (Anon., 1964k), o uvođenju narodnog jezika u liturgiju u SAD-u (Anon., 1964m) i drugim zemljama u svijetu (Anon., 1965f; Anon., 1966e). A kad se u Italiji pojavila jedna knjižica u kojoj je otvoreno kritiziran način na koji se liturgijska obnova provodila, pri čemu je glavna zamjerka bila sve veće odustajanje od latinskog jezika u njoj, list je prenio Papinu osudu stavova iznesenih u knjižici i njegovu potporu uvođenju narodnih jezika u liturgijska slavlja (Anon., 1967c).

Nakon što su se prvi znaci liturgijske obnove počeli pojavljivati i u Hrvatskoj i Jugoslaviji, list te primjere žurno prenosi. Tako, primjerice, prvo podjeljivanje pričesti pod obje prilike osobama koje nisu svećenici (Anon., 1964c), prvu koncelebriranu misu (Anon., 1964j) i sl.

Uredništvo lista pritom je podupiralo one koji su bili skloni uvođenju liturgijskih promjena. Tako, primjerice, kod dvojbi oko službenog jezika, odnosno uvođenju narodnog jezika u liturgiju, već 12. travnja 1964., i prije nego je Biskupska konferencija donijela upute o tome pitanju, prenesen je stav tadašnjeg pomoćnog biskupa senjsko-modruškog Josipa Pavlišića, kako bi »trebalo živi jezik primijeniti u svim liturgijskim činima. Razumije se da ću se ja pridržavati odluka 
Biskupskih konferencija i Svete Stolice, ali moje je mišljenje sada ovakvo i ne vidim razloga da bih ga mogao mijenjati« (Anon., 1964b).

No, unatoč zauzimanju za uvođenje narodnog jezika u liturgiju, list je prenosio i upozorenja onih koji su isticali da latinski jezik i dalje mora biti važan u životu Crkve. Tako, primjerice, prenosi vijest o motupropriju pape Pavla VI. Studia latinitatis o upotrebi latinskog jezika u životu Crkve, a u listu se tumači kako svećenici i dalje trebaju učiti latinski jezik i kako on treba ostati službenim jezikom Crkve, što opet nije u neskladu s narodnim jezicima u liturgiji: »Kad to bude ostvareno, neće se jedinstvo morati čuvati zajedničkim liturgijskim knjigama na latinskom jeziku. Mnogo slobodnije i s većim pouzdanjem prepuštat će se liturgija živim jezicima « (Anon., 1964f). I u razgovoru s ljubljanskim nadbiskupom Jožeom Pogačnikom prenosi njegov stav da se latinski ne bi smio potpuno izbaciti iz Katoličke crkve i njezine liturgije te da bi trebalo barem zadržati pjevane svečane mise na latinskom jeziku, kao i latinski jezik u privatnim misama (Kustić, 1964).

U približavanju vjernicima smisla obnovljene liturgije, u veljači 1965., neposredno prije početka njezine provedbe, objavljen je opširan članak u formi pitanja i odgovora (Lercaro, 1965), a u istom broju — fotografijom stola u gostionici s prigodnim tekstom (Anon., 1965d) i kolumnom Don Jure (Živko Kustić) ukazuju na bit nove liturgije: da Crkva na misi postane obitelj za istim stolom (Kustić, 1965).

S ciljem provedbe liturgijske obnove, početkom 1965. uvedena je i posebna rubrika Put $i$ život, u sklopu koje su vjernici pripremani za promjene koje će uslijediti. Tako se na stranicama te rubrike, primjerice, podupiru i nova rješenja u crkvenoj arhitekturi u duhu shvaćanja novih liturgijskih odredbi: »Učini li se nekome da neke moderne crkve odviše naliče suvremenim predavaonicama, kazališnim i kino-dvoranama, ne treba se ni sablazniti ni odbacivati tu misao kao neumjesnu. Prvi kršćani ugledali su se u javne zgrade svoga vremena - koje čudo ako se današnji kršćani ugledaju u današnje javne zgrade? «(Anon., 1965i).

Kasnije je pojašnjavana i potreba „okretanja oltara“ prema vjernicima (Ladika, 1965; Anon., 1968e), izvješćivano o naputcima koji su dolazili iz Vatikana a odnose se na druge promjene u liturgijskim slavljima (Anon., 1967b), o uvođenju novih misnih kanona (Anon., 1968c; Anon., 1968f), ${ }^{2}$ o dopuštenju da se pričest prima i stojeći (Anon., 1968d) i „na ruku“ (Anon., 1969b; Anon., 1971b; Anon., 1971e; Anon., 1972a; Anon., 1972c) — ali je i objavljivano kad neki domaći biskupi na prostoru svoje biskupije takvu pričest neće dopuštati (Anon., 1971a) te o dopuštenju da pričest bolesnicima nose i laici (Anon., 1972b). List je u više navrata branio i tumačio uvođenje znaka pružanja ruke mira na misnom slavlju (Kustić, 1970; Šagi-Bunić, 1970a; Anon., 1971f; Anon., 1972d), a u pozitivnom je tonu javljao i o drugim novostima, poput uvođenja novih glazbenih oblika u misna slavlja u svijetu, uglavnom prilagođenih mlađim vjernicima (Anon., 1967a).

Sve te promjene nailazile su i na negodovanja i reakcije dijela čitatelja Glasa Koncila, a njihove pisane reakcije uredništvo lista redovito je podvrgavalo kritici

2 I prije nego su novi misni kanoni uvršteni u novi prijevod Misala, tiskani su u zasebnoj knjižici u nakladi Glasa Koncila koja je potom oglašavana u samome listu. Usp. (Anon. 1969c). 
te ih koristilo kao novu prigodu za ponovno tumačenje i promicanje uvođenja promjena. Tako se, primjerice, jedna čitateljica izjasnila protiv oženjenih đakona, uz tvrdnju da ih vjernici u njezinoj župi ne žele, na što joj uredništvo odgovara protupitanjem: »Zar doista ne biste htjeli primiti svetu pričest iz ruke jednog zrelog i prokušanog katoličkog javnog radnika [...] I kakvo vam je to kršćanstvo, kakav katolicizam, izjavljivati da bi vas 'pola otpalo' od Crkve kad bi Koncil izglasao ovo ili ono?« (Anon., 1964i). Drugomu su pak čitatelju iz Zadra zasmetale promjene oltara u crkvama te se pita: »Zašto se poništavaju stari oltari koji sliče pravom Božjem žrtveniku a stavlja se stol koji je sličan onima na kojima se prodaje verdura (povrće) na pijaci«. Uredništvo mu odgovara kako je »prvi žrtvenik na kojemu je Isus prikazao prvu misu, bio [je] stol Posljednje večere. Prema tome novi oltari zaista naliče na pravi Božji žrtvenik «. No, zaključuje list, »nitko ne poništava stare oltare koje je izgradila vjera prošlih stoljeća, ali je sasvim u redu da se novi oltari postavljaju u duhu obnovljenih pogleda na svetu liturgiju« (Anon., 1966b).

I kasnijih godina znale su dolaziti primjedbe čitatelja koji su se opirali „okretanju oltara" i napuštanju latinskog jezika u liturgiji, pa tako anonimni čitatelj (koji se predstavio kao »vjernici, Zagreb«) ističe kako se uvedenim »novotarijama« gubi otajstvenost i mističnost liturgije, koja tako postaje vulgarna. Autor odgovora ga u listu upozorava: »Koji se stavljaju pod parolu „Nihil mutetutur!“ (Ništa mijenjati!) nalaze se u najbližoj opasnost da otpadnu od živog tijela Crkve, da stvore sektu. Tako su redovito u prošlosti nastajali rascjepi (shizme) i hereze. Crkva je kao živo biće rasla i razvijala se, a oni koji to nisu shvatili, morali su zaostati hvaleći okamenjenu prošlost « (Anon., 1968a).

Odgovarajući, pak, onima koji su se protivili „pričešćivanju stojeći“, list na naslovnoj stranici objavljuje fotografiju pape Pavla VI. koji dijeli pričest vjernicima koji stoje, uz izričitu opasku kako to čine jer »neki u Crkvi misle da je to nedostojna novotarija« (Anon., 1969f). Nešto kasnije, objavljen je i stručni članak suradnika Šagi-Bunića na tu temu (Šagi-Bunić, 1969a).

I kad se sredinom 1967. godine u javnosti pojavio letak »katoličkog pokreta VRATIMO SE OLTARU«, u kojem se tvrdilo kako su »u zagrebačkim crkvama maknuti [su] oltari 'versus populum' (prema narodu) jer su svakako nadležni crkveni poglavari vidjeli nepriličnost obreda u kojemu se okreću leđa svetohraništu« autor staje u obranu »okretanja oltara«, te dodaje kako je i »sam Kardinal [Šeper] posvetio crkvu i novi oltar licem prema narodu«, a i sam bi papa Pavao VI. koji »ne dopušta ni previše ni premalo«, zasigurno »da to s novim oltarima nije u redu « i sam reagirao, kao što je reagirao u nekim drugim, stvarno neprikladnima načinima „provedbe“ Koncila (Kustić, 1967a). Već u idućem broju isti autor primjećuje, pozivajući se na jedan članak iz beogradskog časopisa Svet, kako čak i novinari ateisti priznaju da je koncilska obnova liturgije »glavni adut u rukama Katoličke Crkve « jer je »prije svećenik nešto radio na oltaru, a svijet mu gledao u leđa i zabavljao se svojim pjesmama i molitvama, a sada svaki vjernik vidi što svećenik radi, svi mole zajedno sa svećenikom« (Kustić, 1967b). Nedugo potom Don Jure je branio i izmještanje svetohraništa u crkvama s glavnih na pomoćne oltare (Kustić, 1967c). 
Ta „polemika“ oko uređenja liturgijskih prostora u duhu zaključaka Drugog vatikanskog koncila na određeni je način „okončana“ razgovorom s kardinalom Šeperom u božićnom broju lista 1967. godine u kojem je on istaknuo: »Sve je u tome da se promjene narodu jasno rastumače. Npr., koliko je ponegdje poteškoća i protesta bilo s premještanjem Svetohraništa s glavnog oltara. A da svećenici vjernicima jasno kažu: 'Slušajte, svetohraništa u starini nikad nisu bila na oltaru. I u gotičkim crkvama bila su sa strane. I u velikoj većini rimskih crkvi čuva se presv. Sakramenat na pokrajnjim oltarima.' To treba da ljudima razjasnimo. Ako je nama sad zgodnije da oltar bude prema puku, a svetohranište sa strane, onda to nije ništa novo, nego vraćanje na najstariju praksu u Crkvi« (Anon., 1967d).

A nakon što je 1968. objavljen i novi Misal, s misnim kanonom na hrvatskom jeziku, list je u više navrata poticao župnike da ga počnu primjenjivati, odnosno da počnu s liturgijom na narodnom jeziku. »Teško nam je vjerovati da će još biti u našoj zemlji mjesta u kojima bi narodu o velikim blagdanima bila uskraćena misa na hrvatskom jeziku. Svi razlozi govore za to a ne postoji nikakva zapreka sa strane crkvene vlasti. Ako bi negdje župnik oklijevao, bojeći se da narod to ne bi dobro prihvatio ili shvatio, onda je tu zadatak aktivnih vjernika da župniku na vrijeme izraze svoju želju i da ga uvjere kako će narod to primiti oduševljeno. Jer hoće!«, odgovara tako uredništvo jednomu vjerniku koji im piše na tu temu iz svoje župe u Đurmancu (Anon., 1968b). Slično i čitatelju koji upozorava kako se u crkvi Majke Božje Lurdske i dalje istodobno održava više misa na različitim oltarima, što je praksa koju je Drugi vatikanski koncil napustio, odgovara kako bi bilo »poželjno saznati što uprave tih crkava navodi da tako postupaju« (Golubovskij, 1969).

I kad je 1969. propisan novi Obred mise, o tome je najprije javljeno uz pomni opis budućeg izgleda misnog slavlja (Anon., 1969g), a kasnije, kad se s prvom nedjeljom došašća svugdje u svijetu počeo i primjenjivati, još jedanput je opisan novi misni obred (Anon., 1969h) te je objavljen prigodni tekst teologa Bonaventure Dude, koji tumači znakove koje nova misa u sebi sadržava (Duda, 1969), a nešto kasnije Tomislav Šagi-Bunić razradio je i teološku podlogu tog novog obreda (Šagi-Bunić, 1969b).

Kad su dvojica istaknutih kardinala, Alfredo Ottaviani i Antonio Bacci, krajem 1969. istupili protiv Papine konstitucije Missale Romanum, kojom se određuje stupanje na snagu novog Reda mise, list je o tome informirao svoje čitatelje (Anon., 1969a), a nešto kasnije na naslovnoj stranici prenio komentar iz L'Osservatore Romano u kojem se poziva na poslušnost Papi u provođenju novog Obreda mise, te konstatira kako bi, kad je u pitanju nova Papina Uredba kojom je on uveden, »barem oni koji su nedavno branili encikliku Humanae vitae morali priznati vrijednost i zakonitost te Papine odluke« (Anon., 1969e). I inače, list je znao „koristiti“ Papin autoritet kako bi „opravdao“ svoje zauzimanje za obnovu Crkve u duhu Drugog vatikanskog koncila, pa tako i onu na području liturgije. Tako, primjerice, izvješćuje s generalne audijencije pape Pavla VI. u siječnju 1965., na kojoj je Papa govorio o promjenama koje u Sv. misu unosi Konstitucija o liturgiji, stavljajući podnaslov članku »Promjene mogu izgledati bolne, ali katolik ima povjerenja u Papu« (Anon., 1965g). 
Osim promjena u izgledu sv. mise, koje su bile predmetom najvećeg interesa i javnosti i samog lista, Glas Koncila javljao je i pojašnjavao i neke druge segmente liturgijske obnove. Tako, primjerice, list pojašnjava i motive reforme liturgijske godine, kalendara i svetačkih slavlja (Rendić, 1969), te ih kasnije „brani“ od kritika čitatelja (Anon., 1970d), a drugdje javlja i o promjeni formule sakramenta Potvrde (Anon., 1971c).

Svoju potporu koncilskoj obnovi list je pokazivao i prenošenjem pozitivno intoniranih izvješća s tribina i predavanja o koncilskim idejama. Tako, primjerice, javlja o osnivanju koncilske tribine Koncilska misao (Anon., 1965a) te najavljuje i izvješćuje sa svih predavanja održanih u sklopu te tribine. ${ }^{3}$ Isto tako, list je popratio i pokretanje tribine studenata Katoličkog bogoslovnog fakulteta u Zagrebu posvećene promociji koncilskih ideja (Depolo, 1966), kao i neke druge slične inicijative iz toga vremena.

\subsection{Glas Koncila u „procjepu“ između tzv. „progresista“ $i$ „konzervativaca“}

Poslijekoncilska obnova, kako u svijetu tako i u Crkvi u hrvatskom narodu, u velikoj je mjeri bila obilježena i napetostima između tzv. „progresista“, koji su smatrali kako je u crkvenim reformama trebalo otići i puno dalje negoli se to na Koncilu i nakon njega dogodilo, i „konzervativaca“, koji su bili protiv bilo kakve, ili barem protiv znatnije obnove Crkve, smatrajući ju nepotrebnom, štetnom i, u krajnju ruku, „sumnjivom“ u smislu odustajanja od trajnog i provjerenog tradicionalnog crkvenog nauka (Mikić, 2016, 99-123).

Unatoč svoje opredijeljenosti u korist provedbe obnove Crkve u duhu Drugog vatikanskog koncila, čime se pozicioniralo bliže „progresistima“ negoli „konzervativcima“ (no, po mom sudu ipak ne i među „kontestatore“, ${ }^{4}$ koji su osporavali zakonite crkvene autoritete, premda je bilo i takvih optužbi na njihov račun, pa i od nekih predstavnika crkvenog vodstva, 5 što je tema koju, zbog njezina opsega, nije moguće podrobnije obraditi u sklopu ovog rada), uredništvo lista ipak je pokušavalo prevladati sukob i pomiriti te dvije crkvene struje.

U početku je to činilo na način da su se oštre podjele i nepomirljivosti između „progresista“ i ,tradicionalista“ nijekale, odnosno umanjivale. Tako se, primjerice, u jednom redakcijskom komentaru iz studenoga 1965. poručuje kako razlike između pojedinih crkvenih predstavnika, koje su dolazile do izražaja i na samom Koncilu, nipošto ne znače neku podjelu u Crkvi: »Na kraju dolazimo do toga da ne samo [da] nema nikakvih stranaka u Katoličkoj Crkvi nego da čak ni između Crkve i drugih kršćana nema takvih sukoba kakvi postoje između političkih stranaka. Svi će biskupi ponosno i zadovoljno napustiti koncilsku dvoranu. Svaki je

3 Voditelj tribine bio je ravnatelj Glasa Koncila Josip Ladika.

4 Dobar pregled definicije i sadržaja toga naziva vidi u: Bezić, 1975.

5 Primjerice, sarajevski nadbiskup Smiljan Čekada na konferenciji za novinare nakon zasjedanja BKJ u Zagrebu 9. travnja 1970. iznio je kako ni biskupi »u mnogim slučajevima« nisu zadovoljni pisanjem Glasa Koncila jer, kako je pojasnio, »kad se radi, npr. o sporu između zakonitog crkvenog autoriteta i raznih kontestatora (mogu to biti i svećenici), simpatije Glasa Koncila su gotovo uvijek na strani kontestatora« (Anon., 1970a). 
slobodno rekao što je mislio i svi mogu biti zadovoljni što su pridonijeli da se velika Kristova misao potpunije izrazi za ljude našega vremena i za buduća stoljeća « (Anon., 1965h).

Protiv podjele Crkve na „progresivnu“ i „konzervativnu“ list se izjašnjavao i iz pera don Jure. On, primjerice, u jednom tekstu krajem 1967. ističe kako »mi nismo ni konzervativni ni napredni, nego da smo Crkva Božja u kojoj se, ako treba, možemo i posvaditi i pomiriti, i dogovoriti se i razići se, ali sve ostaje u familiji, i na kraju sve koristi toj familiji« (Kustić, 1967d).

No, nešto kasnije, kad je postalo jasno da su „progresisti“ na Zapadu počeli nailaziti i na sve oštrije osude od strane crkvenih autoriteta, pa i samog Pape, list je ponešto promijenio pristup toj temi, ističući kako „progresističkih pretjerivanja“ na Zapadu doduše ima, ali da ih nema i u Crkvi u hrvatskom narodu. Jednom će, tako, zaključiti kako se kod nas primjećuje »da se snage u samoj Crkvi polariziraju i uzajamno optužuju za stavove kojih zapravo nitko ne zastupa«. Zbog toga autor toga prikaza pledira da se — umjesto »lova na vještice«, »nezdrave polarizacije snaga « $\mathrm{i} »$ uzajamnog etiketiranja « — poradi na uzajamnom povjerenju koje će »dovesti do prave koncilske obnove« (Kustić, 1969). Da u Crkvi kod nas, a pogotovo u Glasu Koncila, uopće ne postoji opasnost „osporavateljstva“, barem ne onih „s lijeva“ — za što je list krajem 60-tih i početkom 70-ih godina 20. stoljeća bio sve glasnije optuživan u pojedinim crkvenim krugovima (Čekada, 1971; Mikić, 2016, 342-387) — list je poručio i u jednom komentaru iz druge polovice 1969. godine, ističući kako su kod nas „neupitni“ i vjernost Papi, i pobožnost prema Mariji i iskustvo „križa“. No, dodaje, »treba iskreno pogledati u oči činjenici da ima još podosta onih koji, iz nepokretnosti i neshvaćanja, osporavaju provođenje koncilskih smjernica«, te se treba bojati samo jednoga: »da ta struja toliko ne ojača da izazove reakciju lijevih skretanja, kao 'tuk na luk' " (Anon., 1969d). Kako se to ne bi dogodilo, list je nešto kasnije — uz konstataciju kako »napetosti rastu«, a »namjesto dijaloga, koji bi vodio jasnoći među različitim grupama i shvaćanjima, vlada uzajamna nepovjerljiva šutnja koja rađa nerazumijevanje i prijeti eksplozijama« — predložio otvaranje otvorenog unutarcrkvenog dijaloga o tim spornim pitanjima, te da na čelo koncilske obnove »stanu naši biskupi, da preuzmu sve napore, sve rizike i sve nade takva angažmana« (Anon., 1970c).

U međuvremenu, u listu se pokušalo zauzeti svojevrsnu „srednju liniju“, suprotstavljajući se pretjerivanjima i s jedne i s druge strane, odnosno osuđujući i „progresiste“ i „konzervativce“, ali se ipak zauzimajući za koncilsku obnovu. Tomislav Šagi-Bunić to je jednom prilikom sažeo ovako: »U ovo pokoncilsko vrijeme, postoje u Crkvi opasnosti, postoje i hereze, ali ne postoje samo u jednom smjeru. Nisu one samo među onima koji su željni novih stvari već i među onima koji žele život zaustaviti, koji misle da je najbolje i najpobožnije ostati kod staroga, ništa ne misliti i nikud ne kretati da ne bismo pogriješili. Postoje ne samo 'lijeva skretanja', nego postoje i 'desna skretanja'. Postoje i grijesi propusta, nemara, čekanja, oklijevanja, lijenosti, zadovoljstva samim sobom. Ne griješi samo onaj koji ne prouči dobro Koncila pa se zaleti i načini kakvu glupost, nego ne 
manje griješi i onaj koji jednako ne prouči Koncila i nikuda ne kreće, nego se samo vlada kao sudac svih koji su nešto pokušali i počeli« (Šagi-Bunić, 1967, 3).

I u tom stavu list se poslužio Papinim autoritetom, prenoseći njegove istupe u kojima je kritizirao svako pretjerivanje u crkvenim redovima, kako od strane „progresista“, tako i „tradicionalista“ (Anon., 1966c).

Suprotstavljajući se „tradicionalistima“, koji su nijekali potrebu bilo kakvih promjena u Crkvi, jer bi one, kako su smatrali, bile suprotne nauku Crkve, list je isticao tezu prema kojoj Drugi vatikanski koncil zapravo nije uvođenje „novotarija“, nego baš povratak na izvorne i, tijekom crkvene povijesti, zaboravljene prastare crkvene tradicije. Tako, primjerice, prenosi i vijest o govoru pape Pavla VI. članovima Rimske kurije, u kojem on ističe kako Koncil, premda je bio »velika novost «, ipak nije suprotan »našim autentičnim tradicijama« jer je u mnogočemu bio »samo povratak na izvore, obnova izvornih oblika bogoštovlja, mišljenja i prakse « te nastojanje »da više cijenimo Božje zakone nego običaje koji su nastali tijekom vremena" (Anon., 1966a). Krajem 1971. i početkom 1972. Tomislav Šagi-Bunić pokreće i zasebnu rubriku Glas kršćanske starine, kroz koju, donoseći citate kršćanskih pisaca iz prvih stoljeća kršćanstva, potkrepljuje upravo tezu da koncilska obnova zapravo velikim dijelom znači povratak na izvorne ideje i oblike kršćanstva. Time je, očito, htio autoritetom starih crkvenih otaca poduprijeti one koji se u Crkvi u Hrvatskoj zalažu za obnovu u duhu Drugog vatikanskog koncila.

Premda se gajilo svojevrsni „koncilski optimizam“ i zalagalo se za provedbu koncilskih zaključaka, ipak se nije prešućivalo ni glasove onih koji su prema koncilskim zbivanjima bili oprezni. Tako je primjerice još i prije završetka Koncila objavljen razgovor s tadašnjim skopskim biskupom Smiljanom Čekadom koji, prenoseći dojmove sa zasjedanja, ističe: »Nađe se tu svačega: retorike, tendencije da se bude originalan, jako izražene želje za prilagođivanje duhu vremena, pokušaja da se taktičkim ustupcima, koji idu do krajnje granice istine, otupe razlike između Katoličke Crkve i drugih kršćanskih konfesija. Čuje se tu svašta: i trijeznih opreznih stavova, i smjelih, novotarskih ideja, i naivnih, jedva ozbiljnih prijedloga. - Sve je to bez sumnje zanimljivo, iako svakome ne mora biti simpatično« (Anon., 1964l).

I novoimenovani mostarski biskup koadjutor Pavao Žanić, u svojem prvom razgovoru za list, kritički je progovorio o nekim pojavama u Crkvi koje su uslijedile nakon Drugog vatikanskog koncila: »Mislim da nije dobro sve što je novo zato jer je novo. To bi bila bolest pomodarstva. Ni svako kretanje ne smatram pozitivnim, jer je i razaranje neko kretanje. Omnia probate! Uvijek je u vrtlogu života, u eri vrijenja, potrebno s mnogo razbora promatrati, misliti i trijezno prosuđivati. I teologija mrtvog Boga skriva se u raznim oblicima pod plašt II. Vat. Sabora. U toj se lažnoj i maglovitoj teologiji kapitulantski kaska za duhom materijaliziranog svijeta, bezobzirno se obara katolička dogma, moral i askeza, da bi se ugađalo ušima modernoga čovjeka« (Anon., 1971d).

To istodobno „supostojanje“ na stranicama lista i „progresista“ (u većoj mjeri) i „tradicionalista“ uočili su i analitičari Komisije za vjerska pitanja SR Hrvatske. Tako se u jednoj analizi sadržaja Glasa Koncila tijekom godina 1968. i 
1969. primjećuje kako su na stranicama lista »još uvijek prisutna i konzervativna i reakcionarna stanovišta«, ali su »sve prisutniji autori i stavovi koji se zalažu za koncilsku obnovu, za jedan moderniji pristup aktuelnim problemima«, pa se »stiče utisak da u cjelini GK sve više postaje tribina liberalnih snaga unutar Katoličke Crkve «. Glas Koncila stoga autor analize karakterizira kao »jedno od uporišta reformista, koji međutim odražava ukupna gibanja u Katoličkoj Crkvi«, pa se zato na njegovim stranicama »ukrštaju « različite ideje i koncepcije: »Što se tiče sadržaja potrebno je istaći da se u tim novinama sve više mogu naći vrlo različita, često sasvim suprotna, gledišta o pojedinim pitanjima. Za takvu fizionomija lista opredijelilo se i samo uredništvo koje naglašava da u GK ne pišu istomišljenici, niti dirigirani i cenzurirani informatori, da to nije glasilo nekakve stranke u Crkvi, već da žele slijediti osnovne koncilske kriterije i norme i biti odraz mnogostrukog života Crkve. Stiče se utisak da u tome sve više uspijevaju«(HR-HDA-310).

\subsection{Rekapitulacija provedbe Drugog vatikanskog koncila na stranicama Glasa Koncila}

Kako je vrijeme od završetka Drugog vatikanskog koncila odmicalo, a prijepori u Crkvi postajali sve očitiji, postajalo je sve jasnije da provedba zaključaka Koncila ni u svijetu ni u domaćoj Crkvi neće ići onim intenzitetom i tempom kojeg su neki - a u brojnim svojim tekstovima i sam Glas Koncila — priželjkivali (Mikić, 2016, 123-124). Istaknuti autori lista svoje nezadovoljstvo brzinom provedbe zaključaka Koncila nisu krili, a često su ga potkrepljivali i upozorenjima koja su u tom smislu dolazila od pape Pavla VI. (Anon., 1970b). Na tu je razliku između ,želja“ i „stvarnosti“ list najprije odgovarao poticanjem na strpljenje. »Nama — nestrpljivima — napose onima koji sve to premalo studiraju — Sabor bi mogao reći otprilike ovo: E, djeco Božja, ne budite kratkovidni, ne budite površni! Želite novi svijet? Obnovljen djelovanjem Crkve? Pravo! Samo znajte da kuća mora imati temelj«, poručuje tako u jednom svojem tekstu na stranicama lista Mijo Škvorc (1963). Isti autor svojevrsnu je „rekapitulaciju“ provedbe koncilske obnove na stranicama lista napravio i godinu dana nakon završetka Koncila, odgovarajući pritom i na najčešće prigovore koji su se mogli čuti na račun te obnove, kako iz redova „tradicionalista“, tako i od strane predstavnika „progresista“. Priznajući otvoreno kako se mnogi pitaju nije li »crkvena lađa« skrenula s pravog puta, te kako se i u samoj Crkvi osjeća stanovita »pobuna na brodu«, pri čemu se »pojedini svećenici bore protiv biskupa«, »u pojedinim biskupijama i cijelim kompleksima katoličkih biskupija vodila se gotovo smišljena borba protiv celibata «, a »bacaju se u sumnju [i] same objavljene dogmatske istine«, poput Papine nezabludivosti, stvarne prisutnosti Kristove u euharistiji, djevičanstva Blažene Djevice Marije, nauk o milosti i opravdanju [...] S druge pak strane«, primjećuje autor članka, »mnogima je žao što se u cijeloj pokoncilskoj Crkvi osjetio zapravo neki umor « te se »nakon četiri godine [koje] su uzbuđivale svijet « prva pokoncilska godina »kao da ga je vraćala na staro«. No, navodeći pritom konkretne plodove Koncila, ipak zaključuje kako se »katolicizam ne ras- 
pada, nego se obnavlja«, te kako »nijedno rođenje nije uspješno bez nekog rizika i boli« (Škvorc, 1967).

No, u jednom kasnijem članku, iz 1970., uzrok sporosti provedbe Koncilske obnove detektiran u nositeljima crkvene vlasti, odnosno biskupima. »Umjesto da budu glavni pokretači i pospješitelji obnoviteljskog procesa, mnogi biskupi svoju dužnost i poslije Koncila shvaćaju kao čuvanje primljenog poretka pod svaku cijenu i kao čvrsto držanje uzdi svih gibanja koja idu za tim da se što prije i što brže provede ono što su biskupi sami na Koncilu zaključili [...] Upravni je aparat biskupov u premnogo slučajeva uspio izvršiti svoj utjecaj na biskupa, pa se koncilska obnova ne promiče, nego se samo „propušta“ na najmanje doze: kao najveći grijeh ocjenjuje se tzv. 'trčanje pred rudo' (kao da Crkva nije dobrano zakasnila sa svojim Koncilom!)«(Šagi-Bunić, 1970b).

Nešto kasnije, u ljeto 1972., i don Jure je priznao da rezultati obnove u duhu Drugog vatikanskog sabora u našoj Crkvi i nisu baš „,spektakularni“: »A što se to lijepo dogodilo u Crkvi ovih godina? Što se promijenilo? Ništa, kažem vam ja: ništa! Samo ste nekoliko oltara okrenuli, namjesto nerazumljiva pjevanja na latinskom pjevate koji put malo razumljivije na hrvatskom. Crkvenih odbora i vijeća ili nemate ili su na papiru. Propovijeda se slabo kao i u stara vremena, na vjeronauku je djece sve manje. A među kršćanima ljubavi ni za lijek. Ništa, pustoš i praznina (Kustić, 1972).

\section{Zaključak}

Od osnutka Glasa Koncila u tome je listu pozorno praćeno odvijanje Koncila i izglasavanje njegovih konstitucija, dekreta i deklaracija te su čitateljima, iz pera ponajboljih hrvatskih teologa toga vremena, ti dokumenti strpljivo tumačeni pristupačnim, neakademskim stilom, ali i aktualizirani, odnosno povezivani s konkretnim crkvenim i društvenim prilikama tog vremena (Mikić, 2016, 72). Osim toga, list je bio uporan i u nastojanjima da potakne provedbu nekih od zaključaka Koncila i u konkretnoj Crkvi u hrvatskom narodu, u kojoj je djelovao, osobito na planu liturgijske obnove. No, početkom 70-ih godina na stranicama toga lista u nekoliko navrata je navrata rezignirano zaključeno kako koncilska obnova u nas nije polučila očekivane rezultate. Kako se poslijekoncilska obnova, kako u svijetu tako i kod nas, odvijala u stalnoj napetosti između otpora tzv. „konzervativaca“ i pretjeranih reformskih očekivanja tzv. „progresista“, taj se list na različite načine pokušavao pozicionirati između te dvije „crkvene struje“ tadašnjeg vremena.

\section{Literatura ${ }^{6}$ :}

Anon. (1963). U susret novom proljeću crkve: Želje i proročanstva. Glas Koncila, 2 (7-8), 14.

Anon. (1964a). „Obećana zemlja“ II. Vatikanskog Koncila, Glas Koncila, 3 (21), 2. 
Anon. (1964b). „Stvarnost je živi jezik“: Razgovor s preuzv. g. Josipom Pavlišićem, pomoćnim biskupom senjsko-modruškim. Glas Koncila, 3 (7), 3.

Anon. (1964c). „Vino koje rađa djevice“. U Zagrebu: Sveta pričest pod obje prilike. Glas Koncila, 3 (18), 5.

Anon. (1964d). Koncil razdvojen? Glas Koncila, 3 (21), 5.

Anon. (1964e). Koncil se približava najzanimljivijem nacrtu. Glas Koncila, 3 (21), 3-4.

Anon. (1964f). Latinski jezik postavlja se na pravo i važno mjesto. Glas Koncila, 3 (7), 2.

Anon. (1964g). Naši biskupi na Koncilu. Glas Koncila, 3 (23), 4.

Anon. (1964h). Novost i doseg konstitucije o Crkvi. Glas Koncila, 3 (25), 4.

Anon. (1964i). Ona je protiv oženjenih đakona. Glas Koncila, 3 (22), 15.

Anon. (1964j). Prva koncelebracija u našoj zemlji. Glas Koncila, 3 (22), 2-3

Anon. (1964k). Prvi put u povijesti latinskog obreda primijenjena koncelebracija. Glas Koncila, 3 (11), 12.

Anon. (1964l). Razgovaramo s Koncilskim ocima. Staro vino u novim mjehovima. Glas Koncila, 3 (15), 3.

Anon. (1964m). Sjedinjene Države: Narodni jezik u liturgiji. Glas Koncila, 3 (12), 2.

Anon. (1964n). Za nekoliko mjeseci: Počinje se provoditi liturgijska obnova. Glas Koncila, $3(23), 6$.

Anon. (1964o). Najvažniji dokumenat II Vatikanskog sabora: Dogmatska konstitucija o Crkvi. Glas Koncila, 3 (25), 3.

Anon. (1965a). „Koncilska misao“. Glas Koncila, 4 (18), 14.

Anon. (1965b). „Trinaesta shema“ iz temelja izmijenjena. Glas Koncila, 4 (11), 2.

Anon. (1965c). Bog kojega niječu ateisti nije pravi Bog u kojega mi vjerujemo. Glas Koncila, 4 (1), 5.

Anon. (1965d). Da ne budemo jedni drugima stranci za istim stolom. Glas Koncila, 4 (4), 1.

Anon. (1965e). Izjava o vjerskoj slobodi. Glas Koncila, 4 (16), 2.

Anon. (1965f). Kako je svijet prihvatio liturgijsku obnovu. Glas Koncila, 4 (11), 14.

Anon. (1965g). Papa o promjenama u svetoj misi: Kako prihvatiti novosti u liturgiji. Glas Koncila, 4 (3), 2.

Anon. (1965h). U Crkvi nema stranaka. Glas Koncila, 4 (23), 2.

Anon. (1965i). Zašto su se prvi kršćani odlučili za bazilike. Glas Koncila, 4 (6), 14.

Anon. (1966a). Božje zapovijedi važnije od crkvenih običaja. Glas Koncila, 5 (9), 2.

Anon. (1966b). Novi i stari oltari. Glas Koncila, 5 (3), 15.

Anon. (1966c). Papa izražava žalost i zabrinutost zbog pretjeranosti i na „konzervativnoj““ i na „progresivnoj“ strani u Crkvi. Glas Koncila, 5 (19), 2.

Anon. (1966d). Problem ateizma u koncilskoj konstituciji „Gaudium et spes“: Oblici i korijeni ateizma. Glas Koncila, 5 (2), 3.

Anon. (1966e). Promjene se tek očekuju. Glas Koncila, 5 (4), 14.

Anon. (1967a). Kako je jedna djevojka doživjela „Džez misu“. Glas Koncila, 6 (1), 8.

Anon. (1967b). Novosti u obredu Svete mise. Glas Koncila, 6 (11), 3.

Anon. (1967c). Papa javno ukorio protivnike liturgijske obnove. Glas Koncila, 6 (9), 6.

Anon. (1967d). Razgovarali smo s nadbiskupom zagrebačkim, kardinalom drom Franjom Šeperom: „Mi ne idemo ni za kakvim političkim katolicizmom“. Glas Koncila, 6 (2526), 4.

Anon. (1968a). „Ništa mijenjati!“ Glas Koncila, 7 (25-26), 21. 
Anon. (1968b). Bar na Božić da bude hrvatski! Glas Koncila, 7 (23), 15.

Anon. (1968c). Kanon na hrvatskom. Glas Koncila, 7 (16), 1.

Anon. (1968d). Nepoznati podaci o radu zasjedanja Biskupske konferencije. Glas Koncila, $7(16), 5$.

Anon. (1968e). Oltar kao obiteljski stol. Glas Koncila, 7 (18), 16.

Anon. (1968f). Uvode se tri nova misna kanona. Glas Koncila, 7 (14), 2.

Anon. (1969a). „Bomba Ottaviani-Bacci“: Dva kardinala optužuju papinsku odredbu o novom obredu mise. Glas Koncila, 8 (22), 1-2.

Anon. (1969b). „Pričest na ruku“ sve se više širi. Glas Koncila, 8 (15), 2.

Anon. (1969c). Ne treba čekati. Glas Koncila, 8 (19), 14.

Anon. (1969d). Opasnost od desnih „osporavatelja“. Glas Koncila, 8 (20), 2.

Anon. (1969e). Papu treba slušati i kad nalaže obnovu. Glas Koncila, 8 (24), 1.

Anon. (1969f). Što misli Papa o primanju Pričesti stojeći? Glas Koncila, 8 (12), 1.

Anon (1969g). Novi obred mise. Glas Koncila, 8 (10), 1-2.

Anon. (1969h). Novi obred mise. Glas Koncila, 8 (23), 10.

Anon. (1970a). Naši biskupi govore za tisak. Glas Koncila, 9 (8), 4.

Anon. (1970b). Pavao VI.: Buđenje koje je Koncil pokrenuo počinje se uspavljivati. Glas Koncila, 9 (2), 1-2.

Anon. (1970c). Što ćemo s „katoličkim osporavanjima“? Glas Koncila, 9 (19), 2.

Anon. (1970d). Što se dogodilo s Novom godinom? Glas Koncila, 9 (1), 19.

Anon. (1971a). Đakovački biskup zabranio pričest na ruku. Glas Koncila, 10 (6), 8.

Anon. (1971b). Na teritoriju Jugoslavije dopušteno pričešćivanje „na ruku“. Glas Koncila, $10(5), 4$.

Anon. (1971c). Nova formula sakramenta Potvrde. Glas Koncila, 10 (20), 1.

Anon. (1971d). Razgovor s našim novim biskupima: Mons. Pavao Žanić: „Šteta što nema više svjetla i razboritosti u nama“. Glas Koncila, 10 (3), 4-5.

Anon. (1971e). Zagrebački nadbiskup dopustio pričest na ruku. Glas Koncila, 10 (11), 14.

Anon. (1971f). Zašto zapinje „znak mira“. Glas Koncila, 10 (4), 19.

Anon. (1972a). Framasuni i pričest na ruku. Glas Koncila, 11 (5), 19.

Anon. (1972b). Laici će moći nositi pričest bolesnicima. Glas Koncila, 11 (9), 14.

Anon. (1972c). Pričest na ruku. Glas Koncila, 11 (6), 19.

Anon. (1972d). Rukovanje, mir i bakcili. Glas Koncila, 11 (17), 15.

Baloban, Josip (2000). Pokoncilski pastoralno-teološki pomaci. Bogoslovska smotra, 70 (3-4), 563-564.

Bezić, Živan (1975). Osporavanje u Crkvi. Crkva u svijetu, 3, 193-203.

Čekada, Čedomil (1971). Proigrana šansa: „Fenomen Glasa Koncila“ u svjetlu činjenica $i$ dokumenata. Đakovo: vlastita naklada.

Depolo, Luka (1966). Zagrebački bogoslovi osnovali Koncilsku tribinu. Glas Koncila, 5 (3), 6 .

Duda, Bonaventura (1969). „Znakovitija“ misa. Glas Koncila, 8 (23), 11.

Duda, Bonaventura (1972). I tako je počelo. Glas Koncila, 11 (20), 2-3.

Duda, Bonaventura (1996). Prihvat II. Vatikanskog koncila u Hrvatskoj (II): Fragmenti za buduće cjelovitije prouke. Crkva u svijetu, 31, 257-261.

Golubovskij, V. (1969). Više misa na raznim oltarima. Glas Koncila, 8 (17), 15.

Kustić, Živko (1964). „Crkva mora odložiti feudalno ruho“: Razgovor s mons. Drom Jožetom Pogačnikom, nadbiskupom ljubljanskim. Glas Koncila, 3 (8), 3. 
Kustić, Živko (1965). Samoposluživanje, Glas Koncila, 4 (4), 5.

Kustić, Živko (1967a). Tko to čini grimase? Glas Koncila, 6 (14), 10.

Kustić, Živko (1967b). Po receptu beogradskog „Sveta“. Glas Koncila, 6 (15), 13.

Kustić, Živko (1967c). Tko će protiv Pape i tele Luce! Glas Koncila, 6 (19), 10.

Kustić, Živko (1967d). Evanđelje na Opatijskom festivalu. Glas Koncila, 6 (22), 10.

Kustić, Živko (1969). Jean Danielou: Osporavanje i svjedočenje: Prava knjiga u pravom trenutku. Glas Koncila, 8 (11), 15.

Kustić, Živko (1970). „Kupite si rukavice“. Glas Koncila, 9 (2), 13.

Kustić, Živko (1972). Rezanje repa. Glas Koncila, 11 (15), 12.

Ladika, Josip (1965). Božja obitelj oko očeva stola. Glas Koncila, 4 (7), 17.

Lercaro, Giacomo (1965). Povodom velikog datuma Crkve: 7. ožujka — reforma liturgije. Glas Koncila, 4 (4), 3-4.

Mataušić, Mirko (2006). Prihvat Drugog vatikanskog koncila u Hrvatskoj na primjeru katoličkog tiska i odnosa Crkve prema medijima. Časopis za suvremenu povijest, 38 (2), 499-521.

Mikić, Anto (2016), Crkveno i društveno značenje Glasa Koncila od 1963. do 1972. (Doktorski rad). Hrvatski studiji, Sveučilište u Zagrebu, Zagreb.

Miklenić, Ivan (2013). Pogledi u Glas Koncila. Zagreb: Glas Koncila.

Palanović, Elizabeta (prir.) (1973). Bibliografija Glasa Koncila 1962-1973. Zagreb: Glas Koncila.

Rendić, Smiljana (1969). Što se događa s kalendarom i svecima? Glas Koncila, 8 (11), 7.

Šagi-Bunić, Tomislav (1965a). Crkva je misterij. Glas Koncila, 4 (1), 3.

Šagi-Bunić, Tomislav (1965b). Crkva kao Božji narod. Glas Koncila, 4 (2), 3.

Šagi-Bunić, Tomislav (1965c). Uz koncilsku Konstituciju o Crkvi: Zajednica Duha Svetoga. Glas Koncila, 4 (6), 3.

Šagi-Bunić, Tomislav (1965d). Povodom koncilske Konstitucije o Crkvi: Duh djeluje u Božjem narodu. Glas Koncila, 4 (10), 3.

Šagi-Bunić, Tomislav (1965e). I laici vrše spasiteljsko poslanje Crkve. Glas Koncila, 4 (14), 3.

Šagi-Bunić, Tomislav (1965f). Što je s đakonatom? Glas Koncila, 4 (16), 3-4.

Šagi-Bunić, Tomislav (1965g). Koncil — očitovanje Crkve. Glas Koncila, 4 (18), 3.

Šagi-Bunić, Tomislav (1966a). Monarhija ili aristokracija ili demokracija. Glas Koncila, $5(3), 4$.

Šagi-Bunić, Tomislav (1966b). Što je novo u koncilskoj nauci o braku. Glas Koncila, 5 (4), 3.

Šagi-Bunić, Tomislav (1966c). Uskrsli Krist i ostvarenje progresa. Glas Koncila, 5 (7), 3.

Šagi-Bunić, Tomislav (1966d). Koji su temelji zajedništva među ljudima? Glas Koncila, $5(8), 3$.

Šagi-Bunić, Tomislav (1967). Odgojiti svećenika za novi svijet. Glas Koncila, 6 (15), 3-4.

Šagi-Bunić, Tomislav (1968a). Uz koncilsku Deklaraciju o vjerskoj slobodi. Glas Koncila, 7 (8), 3-4.

Šagi-Bunić, Tomislav (1968b). Odgovorna sloboda (2): Jedina zadaća države na vjerskom području: osigurati slobodu. Glas Koncila, 7 (9), 3.

Šagi-Bunić, Tomislav (1969a). Stajanje ili klečanje? Pred provedbu novog Obreda mise. Glas Koncila, 8 (19), 12-13.

Šagi-Bunić, Tomislav (1969b). Misa nije gluma, nego događaj. Glas Koncila, 8 (24), 4.

Šagi-Bunić, Tomislav (1970a). Zar rukovanje kod mise? Glas Koncila, 9 (5), 5-6. 
Šagi-Bunić, Tomislav (1970b). Svećenik — kome da služi? Glas Koncila, 9 (4), 12.

Škvorc, Mijo (1963). „Što je s tim Koncilom?“ Glas Koncila, 2 (5), 2.

Škvorc, Mijo (1966). „Gaudium et spes — radost i nada“: Pregled i sadržaj najopširnijeg koncilskog dokumenta Pastirske uredbe o Crkvi u suvremenom svijetu. Glas Koncila, $5(1), 4$.

Škvorc, Mijo (1967). Godinu dana nakon Koncila: Zatišje i bura. Glas Koncila, 6 (1), 3-4.

Zovkić, Mato (2005). Recepcija Drugoga vatikanskog sabora u Crkvi u Hrvata. Bogoslovska smotra, 75 (3), 693-696.

Arhivsko gradivo:

Arhiv Glasa Koncila (1963). Odluka nadbiskupa Franje Šepera o izdavanju Glasa Koncila br. 3130/1963 od 31. prosinca 1963. Preslika odluke u: Ur. br. 0/1963.

HR-HDA-310 Komisija za odnose s vjerskim zajednicama Izvršnog vijeća Sabora Socijalističke Republike Hrvatske. Prilog 3. Neke karakteristike sadržaja 'Glasa Koncila' (U toku 1968. i 1969. g.). Kut. 195, br. 112/70.

NAZ (Nadbiskupijski arhiv u Zagrebu). Ostavština Franje Šepera, kutija 48, korice 228. Odluka Franje Šepera o imenovanju Dragutina Hrena glavnim i odgovornim urednikom Glasa s Koncila, 118/pr. od 10. rujna 1963.

The Second Vatican Council and Post-Conciliar Renewal on the Pages of Glas Koncila from 1963 to 1972

Anto Mikić*

\section{Summary}

Based on a personal analysis of the content of Glas Koncila (The Voice of the Council) during the first ten years of its existence (1963 - 1972) as well as archival materials and relevant literature, the author of this paper examines the manner in which this Catholic (bi-)weekly followed the sessions of the Second Vatican Council as they were convened; furthermore, he discusses (post-)conciliar renewal as it was effected within the Church of Croatia and also the tensions and polemics between the "progressives“ and the „conservatives" which marked this process. Hence, the paper analyses the ways in which Glas Koncila promoted (post-)conciliar renewal and endeavoured to make its contribution in this regard. The paper thus investigates a thesis already developed by other authors according to which Glas Koncila played an important part in the reception of the Second Vatican Council within the Church in Croatia.

Key words: Glas Koncila, Second Vatican Council, post-conciliar renewal, progressives, traditionalists, Tomislav Šagi-Bunić, Živko Kustić

* Anto Mikić, Ph.D., Postdoctorand, Croatian Catholic University, Communicology Department. Address: Ilica 242, 10000 Zagreb, Croatia. E-mail: anto.mikic@unicath.hr 